\title{
Chlorophyll fluorescence as a tool to select salinity-tolerant cowpea genotypes
}

\author{
Jailma Ribeiro de Andrade', Sebastião de Oliveira Maia Júnior²*, José Wilson da Silva Barbosa², \\ Aryadne Ellen Vilar de Alencar ${ }^{3}$, Raphael Silva Jovino ${ }^{3}$, Ronaldo do Nascimento ${ }^{2}$
}

\author{
'Federal University of Alagoas, Rio Largo, AL, Brazil \\ ${ }^{2}$ Federal University of Campina Grande, Campina Grande, PB, Brazil \\ 3State University of Paraíba, Campina Grande, PB, Brazil \\ "Corresponding author, email: juniormaiagrari@hotmail.com
}

\begin{abstract}
The use of saline water reduces the growth and productivity of crops, so the need for techniques that make possible the use of this resource such as the use of salinity tolerant genotypes and efficient selection methods are of great importance. Thus, this study aimed to evaluate the tolerance of cowpea (Vigna unguiculata L. Walp.) genotypes to salt stress, through the chlorophyll fluorescence analysis. The experiment was conducted in a protected environment at the Federal University of Campina Grande, Paraíba, Brazil, using a completely randomized design in a $2 \times 10$ factorial arrangement, with three replications, consisting of two levels of irrigation water salinity (0.6 and $5.1 \mathrm{dS} \mathrm{m}^{-1}$ ) and ten cowpea genotypes: (G1: MNCO1-649F-2-1, G2: MNCO3-736F-2, G3: PINGO DE OURO-1-2, G4: BRS GURGUÉIA, G5: BRS MARATAOÃ, G6: MNCO2-676F-3, G7: MNCO2-683F-1, G8: MNCO3-737F-5-4, G9: MNCO3-737F-5-9, and G10: BRS TUMUCUMAQUE). The stem length, stem diameter, SPAD index, and chlorophyll fluorescence transients were evaluated. The G2 and G4 genotypes had the lowest reductions in the growth, stem diameter, initial fluorescence, and primary and maximum photochemical efficiency of PSII, proving to be tolerant to salinity. Chlorophyll fluorescence is a tool that can be used in the selection of salinity-tolerant cowpea genotypes.
\end{abstract}

Keywords: photochemical efficiency, water salinity, Vigna unguiculata

\section{Introduction}

The cowpea (Vigna unguiculata (L.) Walp.) is a leguminous plant of great socioeconomic importance in the North and Northeast regions of Brazil, not only for its popular acceptance but also for being a source of protein, energy, fibers, and minerals (Pereira et al., 2016). It is cultivated mainly in the northeastern arid and semi-arid areas of Brazil, consisting of basic food for the population (Aquino et al., 2017; Oliveira et al., 2018). Due to its characteristics of rusticity and precocity, it is considered a plant adapted to semiarid conditions, and is widely cultivated in rainfed agriculture conditions (in which agriculture production occurs only during the rainy season) and in the irrigated perimeters of Northeast Brazil.

Despite its importance and wide distribution in these regions, some factors have limited their production, such as the water salinity in irrigated areas (Sá et al., 2016; Oliveira et al., 2018). Regarding this aspect, cowpea is considered a moderately salinity tolerant species, tolerating irrigation water salinity of up to $3.3 \mathrm{dS}$ $\mathrm{m}^{-1}$, without compromising productivity (Ayres \& Westcot, 1999). However, the behavior regarding the water electrical conductivity may vary between genotypes, which may have different responses to salinity (Azevedo Neto et al., 2011; Brito et al., 2016; Sá et al., 2016). 
Salinity, in many arid and semi-arid regions, is a serious obstacle to the production system, due to changes in physical and chemical characteristics of soils and the action of specific ions on plant growth (Cavalcante et al., 2010; Melo et al. 2017a). In addition, excess salts in water may affect physiological and biochemical functions, such as the maximum efficiency of photosystem II, resulting in various disturbances which, consequently, compromises the development and production of the cultures (Brito et al., 2016; Oliveira et al. al., 2018). Among the physiological functions, the concentration of pigments (Qados, 2011) and chlorophyll fluorescence are effectively altered in plants under salinity conditions (Brito et al., 2016; Melo et al., 2017a), which allows us to distinguish tolerant from sensitive materials. Thus, this tool can be of great use in the selection of cowpea genotypes, making it possible to identify those most tolerant to salinity.

Some studies have reported the importance of the chlorophyll fluorescence evaluation technique as being efficient in the selection of genotypes more tolerant to salinity, such as in sunflower (Azevedo Neto et al., 2011), citrus (Brito et al., 2016), passion fruit (Freire et al., 2014), and barley (Kalaji et al., 2011). Thus, it was hypothesized in this study that bean genotypes more tolerant to salinity undergo less photosynthetic damage when evaluated by chlorophyll fluorescence.

Given the above, this study aimed to evaluate the chlorophyll fluorescence in cowpea genotypes subjected to different salinity concentrations of irrigation water.

\section{Material and Methods}

The experiment was conducted in a protected environment, a greenhouse at the Academic Unit of Agricultural Engineering (UAEAg) of the Federal University of Campina Grande - UFCG (Campina Grande, Paraíba, Brazil), located at the geographical coordinates $7^{\circ} 15^{\prime} 18^{\prime \prime} \mathrm{S}$ latitude and $35^{\circ} 52^{\prime} 28^{\prime \prime} \mathrm{W}$ longitude, at an altitude of $550 \mathrm{~m}$.

A completely randomized experimental design in a $2 \times 10$ factorial arrangement was used, with three replications referring to irrigation water salinity levels, which were expressed by the electrical conductivity (ECW) of 0.6 and $5.1 \mathrm{dS} \mathrm{m}^{-1}$, being the latter one prepared by adding sodium chloride ( $\mathrm{NaCl}$ ) to the local supply system water (ECW of $0.6 \mathrm{dS} \mathrm{m}^{-1}$ ), and ten cowpea genotypes (G1: MNCO1-649F-2-1, G2: MNCO3-736F-2, G3: PINGO DE OURO-1-2, G4: BRS GURGUÉIA, G5: BRS MARATAOÃ, G6: MNCO2-676F-3, G7: MNCO2683F-1, G8: MNCO3-737F-5-4, G9: MNCO3737F-5-9, and G10: BRS TUMUCUMAQUE). The cowpea genotypes were obtained from Embrapa Meio-Norte. These genotypes were developed with the intention of being cultivated under the prevailing climatic conditions of the semi-arid region of Northeast Brazil.

Each experimental unit consisted of a 20-L plastic pot, which was filled with soil of which physicochemical characteristics are shown in Table 1.

Table 1. Physicochemical characterization of the soil used in the experiment

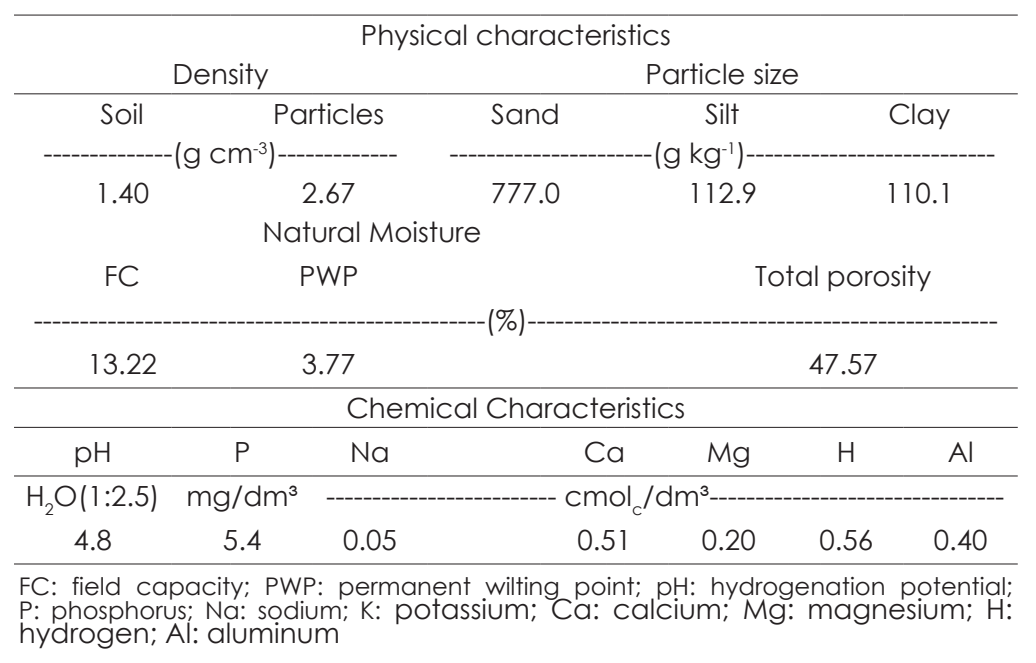


The soil was fertilized according to the recommendations of Novais et al. (1991), for pots in protected cultivation. Three seeds were sown in each pot, and five days after germination, thinning was performed, leaving only one plant per pot.

The plants were irrigated daily with low salinity water $\left(0.6 \mathrm{dS} \mathrm{m}^{-1}\right)$ in order to maintain the soil characteristics close to that of field capacity until thinning; then the treatments with saline water (5.1 dS $\mathrm{m}^{-1}$ ) were started.

To obtain water electrical conductivity of $5.1 \mathrm{dS} \mathrm{m}^{-1}, \mathrm{NaCl}$ was added to the water of $0.6 \mathrm{dS} \mathrm{m}^{-1}$. The amount of sodium chloride (A $\mathrm{NaCl}$ ) used in the water preparation was determined considering the water initial electrical conductivity, according to the method proposed by Richards (1954):

$\mathrm{A} \mathrm{NaCl}\left(\mathrm{mg} \mathrm{L}^{-1}\right)=640 \times$ (desired ECW - initial ECW) Equation 1

Where: A $\mathrm{NaCl}$ corresponds to the amount of $\mathrm{NaCl}$ added to water, and $\mathrm{ECW}$ is the water electrical conductivity, in $\mathrm{dS} \mathrm{m}^{-1}$.

The water volume to be used was calculated according to evapotranspiration demand. The water consumption was determined by the difference between the water volume used and the drainage volume, in order to make the moisture close to that of field capacity, obtaining a leaching fraction of 0.2 , as follow:

$$
I V=(W V-D V) /(1-L F) \text { Equation } 2
$$

Where: IV = Water volume to be used in the irrigation $(\mathrm{mL}) ; \mathrm{WV}=$ Water volume used in previous irrigation $(\mathrm{mL}) ; \mathrm{DV}=$ Water volume drained in previous irrigation $(\mathrm{mL})$; and $L F=$ Leaching fraction (0.2).

At 60 days after saline treatment, plant height or the main branch length, stem diameter, and chlorophyll fluorescence were evaluated. The main branch length was measured from the root collar to the apical meristem, using a tape measure graded in centimeters. The stem diameter was measured at $3 \mathrm{~cm}$ above the ground surface, using a digital caliper.

Chlorophyll fluorescence was measured using a Portable Fluorometer (PEA - Plant Efficiency Analyser, Hansatech Norfolk, UK) in fully expanded leaves. The leaves were subjected to a dark adaptation period, using specific clips for $\approx 30$ minutes to induce complete oxidation of the reaction centers (Maxwell \& Johnson, 2000). The following chlorophyll fluorescence transients were evaluated: initial fluorescence (Fo), maximum fluorescence (Fm), variable fluorescence (Fv), primary photochemical efficiency of photosystem II (Fv/Fo), and maximum photochemical efficiency of photosystem II (Fv/Fm).

The data were subjected to analysis of variance ('F' test). In the case of significant effects, the Scott-Knott test $(p<0.05)$ and the Tukey test $(p<0.05)$ were performed for the genotype and the salinity factors, respectively.

\section{Results and Discussion}

The increase in irrigation water salinity resulted in a reduction in plant growth in all bean genotypes. The G2 and G4 had the lowest reductions whereas the other genotypes had the highest ones (Table 2). Similarly, Sousa et al. (2014) found that increased irrigation water salinity affected the growth of cowpea plants. The salinity of the irrigation water causes a reduction in plant growth because, firstly, it reduces soil osmotic potential, which consequently increases the retention forces, decreasing the absorption of water by the plant and the cell turgescence, which affects the elongation rates and cell division (Santos et al., 2016; Araújo et al., 2017). Therefore, it can be suggested that this condition led to the lowest growth in the studied genotypes, specifically, in the most sensitive ones.

The stem diameter significantly varied between the genotypes subjected to the lowest salinity $\left(0.6 \mathrm{dS} \mathrm{m}^{-1}\right)$, and the G5, G6, G8, and G10 had the largest diameters (Table 2). However, the increase in salinity did not affect the stem diameter in G1 and G2. Similar to the main branch growth, this characteristic is also associated with the plant turgescence. Nevertheless, there seems to be no high variation in bean genotypes as a result of the increase in salinity.

The chlorophyll index (SPAD) did not vary among the genotypes subjected to low salinity. However, increase in salinity did not only affect the G1, G2, G4, and G7 genotypes; the G9, G10, G6, and G3 were the most affected ones, with 
reductions of $44,43,40$ and $29 \%$, respectively, in comparison with those subjected to low salinity (Table 2). As the SPAD index is well correlated with the pigment contents, its reduction indicates a decrease in the pigments in response to salinity (Qados, 2011; Koyro et al., 2013). In pepper plants (Capsicum annuum L.), photosynthetic pigments were drastically affected by salinity, and chlorophyll a was the most sensitive, with a reduction of $50 \%$ when subjected to water EC of $9 \mathrm{dS} \mathrm{m}^{-1}$ (Melo et al., 2017a). Pigment reduction also occurred in fava (Vicia faba L.) due to the increased salinity (Qados, 2011). These reductions probably affected the absorption and use of light energy, as it can be observed in the chlorophyll fluorescence measurements in this study.

The increase in water salinity affected the initial fluorescence (Fo) of the studied genotypes, except for G2, G4, and G8 (Table 2). The G9, G6, $\mathrm{G} 5$, and $\mathrm{G} 3$ were the genotypes most affected

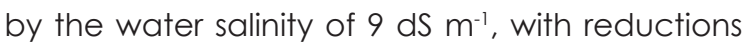
of $19,18,16$ and $10 \%$, respectively, in comparison with those subjected to low salinity, indicating sensitivity to salt stress. The increase in Fo may be interpreted as a damage to the PSIl light-collecting complex or as a decrease in the capacity of transferring the excitation energy from the antenna to the PSII (Baker, 2008; Azevedo Neto et al., 2011; Kalaji et al., 2011), as it is observed in the present study. These results involve a higher energy loss per chlorophyll complex, which may be related to the higher difficulty of plants to absorb water and to optimize the process of light energy consumption (Brito et al., 2016).

Table 2. Main branch length (MBL), stem diameter (SD), SPAD index, and initial fluorescence (Fo) in different cowpea genotypes under salt stress

\begin{tabular}{|c|c|c|c|c|c|c|c|c|}
\hline \multirow{3}{*}{ Genotypes } & \multicolumn{2}{|c|}{$M B L(\mathrm{~cm})$} & \multicolumn{2}{|c|}{$\mathrm{SD}(\mathrm{mm})$} & \multicolumn{2}{|c|}{ SPAD Index } & \multicolumn{2}{|c|}{ Fo } \\
\hline & \multicolumn{8}{|c|}{ Salinity (dS $\left.\mathrm{m}^{-1}\right)$} \\
\hline & 0.6 & 5.1 & 0.6 & 5.1 & 0.6 & 5.1 & 0.6 & 5.1 \\
\hline G1 & 53.5Ad & $24.0 \mathrm{Bb}$ & 7.01AC & $6.48 \mathrm{Aa}$ & 46.7Aa & $41.2 \mathrm{Ab}$ & $384.6 \mathrm{Ba}$ & 487.3Aa \\
\hline G2 & 186.1 Aa & $64.5 \mathrm{Ba}$ & $7.49 A C$ & 6.47Aa & 55.7Aa & $50.0 \mathrm{Aa}$ & $389.5 \mathrm{Aa}$ & $363.6 \mathrm{Ab}$ \\
\hline G3 & 45.0Ad & $30.5 \mathrm{Bb}$ & $8.95 \mathrm{Ab}$ & $6.43 \mathrm{Ba}$ & $58.2 \mathrm{Aa}$ & $40.9 \mathrm{Bb}$ & $421.3 \mathrm{Ba}$ & $465.0 \mathrm{Aa}$ \\
\hline G4 & $198.5 \mathrm{Aa}$ & $48.5 \mathrm{Ba}$ & $8.63 \mathrm{Ab}$ & $6.23 \mathrm{Ba}$ & $56.4 \mathrm{Aa}$ & $49.4 \mathrm{Aa}$ & $417.3 \mathrm{Aa}$ & $402.6 \mathrm{Ab}$ \\
\hline G5 & 53.3Ad & $32.0 \mathrm{Bb}$ & $9.39 \mathrm{Aa}$ & $7.63 \mathrm{Ba}$ & 55.3Aa & $44.6 \mathrm{Ba}$ & $393.0 \mathrm{Ba}$ & 469.0Aa \\
\hline G6 & $47.0 \mathrm{Ad}$ & $30.0 \mathrm{Bb}$ & $9.36 \mathrm{Aa}$ & $6.22 \mathrm{Ba}$ & $58.9 \mathrm{Aa}$ & $35.0 \mathrm{Bb}$ & $380.6 \mathrm{Ba}$ & 468.0Aa \\
\hline G7 & $52.6 \mathrm{Ad}$ & $27.5 \mathrm{Bb}$ & $8.45 \mathrm{Ab}$ & $5.55 \mathrm{Ba}$ & $58.5 \mathrm{Aa}$ & 54.7Aa & 393.3Ba & $474.3 \mathrm{Aa}$ \\
\hline G8 & 34.0Ad & $19.5 \mathrm{Bb}$ & $10.19 \mathrm{Aa}$ & $6.27 \mathrm{Ba}$ & 63.2Aa & $46.7 \mathrm{Ba}$ & $382.6 \mathrm{Aa}$ & $393.6 \mathrm{Ab}$ \\
\hline G9 & $78.5 \mathrm{AC}$ & $24.0 \mathrm{Bb}$ & $8.12 A C$ & 6.35Ba & $65.2 \mathrm{Aa}$ & $36.2 \mathrm{Bb}$ & $375.6 \mathrm{Ba}$ & 468.0Aa \\
\hline G10 & $131.0 \mathrm{Ab}$ & $35.0 \mathrm{Bb}$ & 8.77Ab & $6.23 \mathrm{Ba}$ & $63.4 \mathrm{Aa}$ & $35.6 \mathrm{Bb}$ & $400.3 \mathrm{Ba}$ & 454.0Aa \\
\hline MSD & \multicolumn{2}{|c|}{5.20} & \multicolumn{2}{|c|}{0.33} & \multicolumn{2}{|c|}{2.98} & \multicolumn{2}{|c|}{11.06} \\
\hline CV\% & \multicolumn{2}{|c|}{16.42} & \multicolumn{2}{|c|}{8.64} & \multicolumn{2}{|c|}{11.27} & \multicolumn{2}{|c|}{5.06} \\
\hline
\end{tabular}

The maximum fluorescence (Fm) and variable fluorescence (Fv) were only influenced by the increase in water salinity, regardless of the bean genotype (Table 3). The reduction in Fv and $\mathrm{Fm}$ is due to the decrease in chlorophyll efficiency in response to the increased salinity, indicating ionic toxicity (Melo et al., 2017b), although there has been no salinity effect regarding the genotypes, as it was observed in Fv/Fo and Fv/ $\mathrm{Fm}$.

The primary photochemical efficiency of PSII (Fv/Fo) was not affected by water salinity only in the G2 and G4 genotypes (Table 3). With regards, the other genotypes, the Fv/Fo was reduced in response to the increased salinity, and the G5, G10, and G6 were the most affected genotypes, with decreases of 32,28 and $26 \%$, respectively, in comparison with those subjected to low salinity.

The Fv/Fo ratio has also been recommended to detect changes induced by salt stress (Kalaji et al., 2011) because, although it provides the same basic information like the Fv/ $\mathrm{Fm}$, it is able to identify small variations (Azevedo Neto et al., 2011). This was confirmed in our study, as it can be observed in the comparison between both variables, corroborating the results found by Azevedo Neto et al. (2011) in sunflower genotypes under salt stress. The Fv/Fo ratio has also been used to select salinity tolerant barley 
genotypes (Kalaji et al., 2011). According to these authors, the Fv/Fo is the most sensitive component of the electron transport chain and, therefore, a decrease in this ratio results from the damage in the photosynthetic electron transport. Thus, these results confirm the importance of evaluating the $\mathrm{Fv} / \mathrm{Fo}$ ratio in the selection of bean genotypes considering their tolerance to salinity.

Like the primary photochemical efficiency, the maximum photochemical efficiency of PSII (Fv/Fm) was not affected by water salinity only in the $\mathrm{G} 2$ and $\mathrm{G} 4$ genotypes (Table 3). On the other hand, the G5, G1, and G10 were the most affected genotypes, with reductions of 9,6 and $5.9 \%$, respectively, in comparison to those subjected to low salinity. The genotypes studied here had the same behavior both regarding the Fv/Fm and Fv/Fo; however, there were more pronounced reductions in the Fv/Fo, which evidences the importance of evaluating this ratio to detect and/or confirm the $\mathrm{Fv} / \mathrm{Fm}$ variations. Nevertheless, the $\mathrm{Fv} / \mathrm{Fm}$ is widely reported as efficient in selecting salinity tolerant genotypes, such as in citrus (Brito et al., 2016) and passion fruit (Freire et al., 2014). Thus, it can be suggested that Fv/Fo, Fv/Fm, and Fo, together, were efficient in the selection of salinity tolerant bean genotypes, as it was observed in the distinction between $\mathrm{G} 2$ and $\mathrm{G} 4$.

Table 3. Maximum fluorescence (Fm), variable fluorescence (Fv), primary photochemical efficiency (Fv/Fo), and maximum photochemical efficiency of PSII (Fv/Fm) of different cowpea genotypes under salt stress

\begin{tabular}{|c|c|c|c|c|c|c|c|c|}
\hline \multirow{3}{*}{ Genotypes } & \multicolumn{2}{|c|}{$\mathrm{Fm}$} & \multicolumn{2}{|c|}{$\mathrm{Fv}$} & \multicolumn{2}{|c|}{$\mathrm{Fv} / \mathrm{Fo}$} & \multicolumn{2}{|c|}{$\mathrm{Fv} / \mathrm{Fm}$} \\
\hline & \multicolumn{8}{|c|}{ Salinity $\left(\mathrm{dS} \mathrm{m}^{-1}\right)$} \\
\hline & 0.6 & 5.1 & 0.6 & 5.1 & 0.6 & 5.1 & 0.6 & 5.1 \\
\hline G1 & 2282.0Aa & 2307.3Aa & 1897.6Aa & 1820.0Aa & 4.93Aa & $3.73 \mathrm{Bb}$ & $0.83 \mathrm{Aa}$ & $0.78 \mathrm{Bb}$ \\
\hline G2 & $2340.6 \mathrm{Aa}$ & $2018.0 \mathrm{Ba}$ & 1951.1Aa & $1654.3 \mathrm{Ba}$ & $5.01 \mathrm{Aa}$ & $4.55 \mathrm{Aa}$ & $0.83 \mathrm{Aa}$ & $0.81 \mathrm{Aa}$ \\
\hline G3 & $2251.0 \mathrm{Aa}$ & 2074.6Aa & $1829.6 \mathrm{Aa}$ & 1609.6Aa & 4.35Ab & $3.46 \mathrm{Bb}$ & $0.81 \mathrm{Ab}$ & $0.77 \mathrm{Bb}$ \\
\hline G4 & $2199.6 \mathrm{Aa}$ & 2089.0Aa & $1782.3 \mathrm{Aa}$ & 1686.3Aa & $4.26 \mathrm{Ab}$ & $4.18 \mathrm{Aa}$ & $0.80 \mathrm{Ab}$ & $0.80 \mathrm{Aa}$ \\
\hline G5 & $2306.6 \mathrm{Aa}$ & $2020.3 B a$ & 1913.6Aa & 1551.3Aa & $4.90 \mathrm{Aa}$ & $3.30 \mathrm{Bb}$ & $0.83 \mathrm{Aa}$ & $0.76 \mathrm{Bb}$ \\
\hline G6 & $2210.0 \mathrm{Aa}$ & $2130.3 \mathrm{Aa}$ & 1829.3Aa & 1662.3Aa & $4.80 \mathrm{Aa}$ & $3.55 \mathrm{Bb}$ & $0.82 \mathrm{Aa}$ & $0.78 \mathrm{Bb}$ \\
\hline G7 & 2228.3Aa & 2192.0Aa & 1835.0Aa & 1717.6Aa & $4.66 \mathrm{Aa}$ & 3.62Bb & $0.82 \mathrm{Aa}$ & $0.78 \mathrm{Bb}$ \\
\hline G8 & 2262.3Aa & 1927.0Ba & 1879.6Aa & 1533.3Ba & $4.93 \mathrm{Aa}$ & $3.91 \mathrm{Bb}$ & $0.83 \mathrm{Aa}$ & $0.79 \mathrm{Bb}$ \\
\hline G9 & $2154.0 \mathrm{Aa}$ & 2197.0Aa & 1778.3Aa & 1729.0Aa & $4.73 \mathrm{Aa}$ & $3.69 \mathrm{Bb}$ & $0.82 \mathrm{Aa}$ & $0.78 \mathrm{Bb}$ \\
\hline G10 & 2254.0Aa & $2195.0 \mathrm{Ba}$ & $2153.6 \mathrm{Aa}$ & $1741.0 \mathrm{Ba}$ & $5.38 \mathrm{Aa}$ & $3.83 \mathrm{Bb}$ & $0.84 \mathrm{Aa}$ & $0.79 \mathrm{Bb}$ \\
\hline MSD & \multicolumn{2}{|c|}{74.45} & \multicolumn{2}{|c|}{69.59} & \multicolumn{2}{|c|}{0.16} & \multicolumn{2}{|c|}{0.005} \\
\hline CV\% & \multicolumn{2}{|c|}{6.49} & \multicolumn{2}{|c|}{7.50} & \multicolumn{2}{|c|}{7.52} & \multicolumn{2}{|c|}{1.38} \\
\hline
\end{tabular}

Different uppercase letters indicate a significant difference between water salinity levels by the Tukey test $(p<0.05)$; different lowercase letters indicate a significant difference between genotypes at each salinity level by the Scott-Knott test ( $p<0.05)$. MSD: Minimum significant difference, CV: coefficient of variation.

\section{Conclusions}

Chlorophyll fluorescence is a tool that can be used to select salinity tolerant bean genotypes, specifically, through initial fluorescence (Fo), primary photochemical efficiency of PSII (Fv/Fo), and maximum photochemical efficiency of PSII (Fv/Fm), considering their combined behavior and relationship to plant growth.

Based on the chlorophyll fluorescence analysis, the G2: MNCO3-736F-2 and G4: BRS GURGUÉlA were the most salinity tolerant genotypes; the others proved to be sensitive to the conditions studied.

\section{References}

Aquino, J.P.A., Bezerra, A.A.C., Alcântara Neto, F., Lima, C.J.G.S., Sousa, R.R. 2017.
Morphophysiological responses of cowpea genotypes to irrigation water salinity. Revista Caatinga 30:1001-1008.

Araújo, E.D., Melo, A.S., Rocha, M.S., Carneiro, R.F., Rocha, M.M. Genotypic variation on the antioxidative response of cowpea cultivars exposed to osmotic stress. 2017. Revista Caatinga 30: $928-93$

Ayers, R.S., Westcot, D.W. 1999. A qualidade de água na agricultura. 2.ed. Campina Grande: UFPB. 153p. (Estudos FAO. Irrigação e Drenagem, 29). Tradução de Gheyi, H.R., Medeiros, J.F., Damasceno, F.A.V.

Azevedo Neto, A.D., Pereira, P.P.A., Costa, D.P., Santos A.C.C. 2011. Fluorescência da clorofila como ferramenta possível para a seleção de tolerância à salinidade em girassol. Revista Ciência Agronômica 42: 893-897. 
Baker, N.R. Chlorophyll fluorescence: A probe of photosynthesis in vivo. 2008. Annual Review of Plant Biology 1 13: 59-89.

Brito, M.E.B., SÁ, F.V.S., Soares Filho, W.D.S., Silva, L.D.A., Fernandes, P.D. Gas exchange and chlorophyll fluorescence of citrus rootstock varieties under salt stress. 2016. Revista Brasileira de Fruticultura 38: 1-8.

Cavalcante, L. F., Vieira, M. S., Santos, A. F., Oliveira, W. M., Nascimento, J. A. M. 2010. Água salina e esterco bovino líquido na formação de mudas de goiabeira cultivar Paluma. Revista Brasileira de Fruticultura 32: 251-261.

Freire, J.L.O., Dias, T.J., Cavalcante, L.F., Fernandes, P.D., Neto, A.J.L. 2014. Rendimento quântico e trocas gasosas em maracujazeiro amarelo sob salinidade hídrica, biofertilizante e cobertura morta. Revista Ciência Agronômica 45: 82- 91

Kalaji, H.M., Govindjee, BOSA, K., Koscielniak, J., Zuk-Gołaszewska, K. 2011. Effects of salt stress on photosystem II efficiency and CO2 assimilation of two Syrian barley landraces. Environmental and Experimental Botany 73:64-72.

Koyro, H., Hussaina, T., Huchzermeyerc, B., Khana, M.A. 2013. Photosynthetic and growth responses of a perennial halophytic grass Panicum turgidum to increasing $\mathrm{NaCl}$ concentrations. Environmental and Experimental Botany 91: 22-29.

Maxwell C., Johnson G.M. 2000. Chlorophyll fluorescence - a practical guide. Journal of Experimental Botany 51: 659-668.

Melo, H.F.D., Souza, E.R.D., Duarte, H.H., Cunha, J.C., Santos, H.R. 2017a. Gas exchange and photosynthetic pigments in bell pepper irrigated with saline water. Revista Brasileira de Engenharia Agrícola e Ambiental 21:38-43.

Melo, H.F.D., Souza, E.R.D., Cunha, J.C. 2017b. Fluorescence of chlorophyll a and photosynthetic pigments in Atriplex nummularia under abiotic stresses. Revista Brasileira de Engenharia Agrícola e Ambiental 21: 232-237.

Novais, R.J., Neves, J.C.L., Barros, N.F. 1991. Ensaios em ambiente controlado. In: Oliveira, A.J., Garrido, W.E., Araújo, J.D., Lourenço, L. Métodos de pesquisa em fertilidade do solo. Brasília: Embrapa 189-254.

Oliveira, W.J., Souza, E.R., Santos, H.R.B., Silva, E.F.F., Duarte, H.H.F., Melo, D.V.M. 2018. Fluorescência da clorofila como indicador de estresse salino em feijão caupi. Revista Brasileira de Agricultura Irrigada 12: 2592-2603.

Pereira, T.S., Lima, M.D.R., Paula, L.S., Lobato, A.K.S. 2016. Tolerance to water deficit in cowpea populations resulting from breeding program: detection by gas exchange and chlorophyll fluorescence. Indian Journal of Plant Physiology 21: 171-178.

Qados, A.M.A. 2011. Effect of salt stress on plant growth and metabolism of bean plant Vicia faba (L.). Journal of the Saudi Society of Agricultural Sciences 10: 7-15.

Richards, L.A. 1954. Diagnosis and improvement of saline and alkali soils. Washington D.C.: U.S. Salinity Laboratoy. 160p.

Sá, F.V.S., Paiva, E.P., Torres, S.B., Brito, M.E.B., Nogueira, N.W., Frade, L.J.G., Freitas, R.M.O. 2016. Seed germination and vigor of different cowpea cultivars under salt stress. Comunicata Scientiae 7: 450-455.

Santos, J.B., Gheyi, H.R., de Lima, G.S., Xavier, D.A., Cavalcante, L.F., Centeno, C. R.M. 2016. Morfofisiologia e produção do algodoeiro herbáceo irrigado com águas salinas eadubado com nitrogênio. Comunicata Scientiae 7: 86-96.

Sousa, G.G., Araújo Viana, T.V., Lacerda, C.F., Azevedo, B.M., Silva, G.L., Costa, F.R.B. 2014. Estresse salino em plantas de feijão-caupi em solo com fertilizantes orgânicos. Revista agro@ mbiente on-line 8: 359-367. 